\title{
ENTREVISTA COM LÍVIA SUASSUNA
}

\section{Interview with Lívia Suassuna}

Silvio Profirio da SILVA, FACIG/Secretaria de Educação do Recife - PCR ${ }^{1}$ Josete Marinho de LUCENA, UFPB ${ }^{2}$

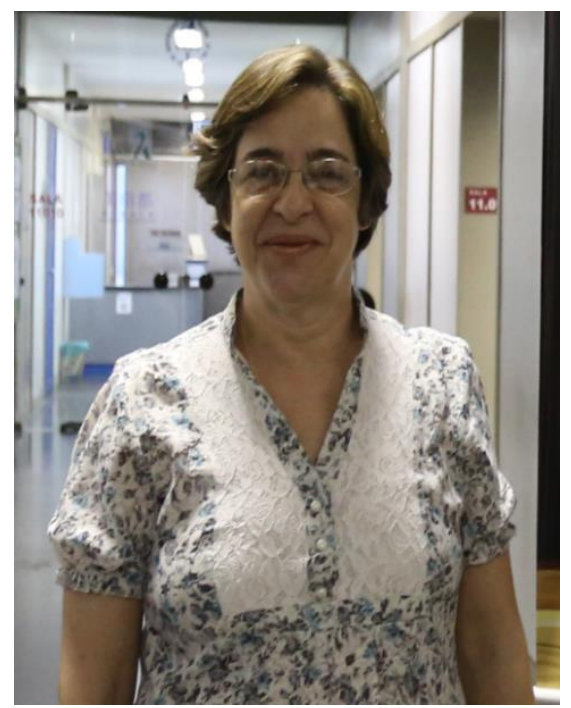

Fonte: A entrevistada, 2017.

Ao longo de um amplo contingente de décadas, o trabalho pedagógico do ensino de língua materna fomentou a efetivação de práticas de metalinguagem. Esse tratamento refletiu-se no ensino da produção de texto, que esteve diretamente vinculado a distintos procedimentos. De um lado, a memorização de componentes e de regras gramaticais, bem como sua aplicação nas atividades de produção textual. De outro lado, a imitação de elementos estruturais típicos das tipologias textuais.

Até meados da década de 1950, o trabalho pedagógico do ensino da produção de texto concedeu primazia à sacralização da norma. Dizendo de outra forma, o ensino da produção de texto esteve calcado na potencialização de práticas de metalinguagem. Nessas práticas, predominava a abordagem de regras concernentes aos componentes gramaticais, bem como o seu uso nas produções escritas do alunado. Para realização dessa faceta, os gêneros discursivos procedentes da esfera literária ilustravam o padrão de escrita em sintonia com a sacralização da norma, como aponta Marcuschi (2010).

Na década de 1960, o trabalho pedagógico do ensino da produção de texto passou a primar pela imitação de arquiteturas textuais consagradas, mais especificamente, pela imitação de elementos estruturais. Sob a ótica dessa concepção de linguagem, o ensino da produção textual esteve diretamente atrelado à técnica cujo cerne estava na mecanicidade da imitação estrutural, bem como na aplicação de procedimentos repetitivos. Nessa conjectura, o trabalho pedagógico do ensino da produção de texto teve como cerne as técnicas de redação e, em especial, as

\footnotetext{
${ }^{1}$ Mestre pelo Programa de Pós-Graduação em Linguística e Ensino da Universidade Federal da Paraíba UFPB. Professor do curso de Licenciatura em Pedagogia na Faculdade de Ciências Humanas e Sociais de Igarassu - FACIG. profirio.silvio@bol.com.br

${ }^{2}$ Doutora em Linguística pela Universidade Federal do Ceará - UFC. Professora Adjunta na Universidade Federal da Paraíba - UFPB, vinculada Departamento de Letras Clássicas e Vernáculas DLCV, atuando nos Cursos de Letras Português e Letras Libras e no Programa de Pós-Graduação em Linguística e Ensino - PPGLE. josetemarinho.ufpb@gmail.com
} 
sequências tipológicas (descrição, dissertação e narração). Do alunado, era requerida a imitação de distintos componentes estruturais dessas tipologias, tais como: formatos, elementos fraseológicos, organização frasal, léxico etc., conforme pontua Luna (2012).

Na visão de Santos (2002), a década de 1980 tem como marca inegável a considerável propalação de trabalhos acadêmicos relativos ao trabalho pedagógico do ensino da leitura e da escrita. Esses trabalhos estão diretamente vinculados aos postulados sociointeracionistas e discursivos da linguagem. Desses postulados, procede a noção de linguagem como forma de interação social. Sob o lastro desses postulados, o texto adquire o patamar de objeto de ensino.

Entre o cabedal de teorizações postas pelos postulados sociointeracionistas e discursivos da linguagem, estão os trabalhos da Linguística de Texto. No dizer de Koch \& Elias (2009), sob a ótica dessa abordagem teórica da Linguística, a produção de texto (escrita e oral) pode ser definida como uma prática interativa resultante da concatenação de conhecimentos linguísticos, enciclopédicos e textuais, bem como da mobilização de práticas cognitivas e metacognitivas.

Desde meados dos anos de 1990, essa perspectiva de produção de texto vem permeando os documentos oficiais tocantes à Educação Básica (Parâmetros Curriculares Nacionais - PCNs, Orientações Curriculares Nacionais para o Ensino Médio - OCEMs etc.), as rotinas educacionais e os materiais didáticos (livros didáticos de Língua Portuguesa). Isso tem fomentado um amplo leque de modificações no trabalho pedagógico do ensino da produção de texto.

Para Marcuschi (2010), o trabalho pedagógico do ensino da produção de texto está intrinsecamente vinculado aos gêneros discursivos provenientes de diferenciadas esferas sociocomunicativas, a saber, a científica, a cotidiana, a escolar, a jornalística, a literária, a midiática, a política, a publicitária etc. Os Parâmetros Curriculares Nacionais de Língua Portuguesa - PCNs orientam que o trabalho pedagógico do ensino da produção textual contemple a abordagem das características constitutivas dos gêneros discursivos (propósito comunicativo, conteúdo temático, forma composicional e estilo verbal), assim como as suas condições de produção e circulação.

Além disso, os PCNs orientam que o trabalho pedagógico do ensino da produção de texto mobilize situações de interlocução formais e informais, bem como privadas ou públicas. A realização dessa faceta está diretamente relacionada com a usabilidade dos gêneros discursivos (escritos e orais) propalados nas tramas do dia a dia. Diante dessa acepção, o ensino da produção de texto tem como meta fomentar o acesso do alunado a distintas situações de interação, em especial a situações procedentes do âmbito extraescolar, o que alça a escrita ao patamar de prática social (CAVALCANTE \& MARCUSCHI, 2007; LEAL \& MELO, 2007).

Diante do exposto, realizamos a presente entrevista com a Professora Dr. ${ }^{a}$ Lívia Suassuna, almejando ampliar nossos conhecimentos a respeito dos diferenciados aspectos atinentes ao trabalho pedagógico relativo ao ensino da produção de texto. Com esse olhar, esperamos que esta entrevista acarrete contributos, em prol da formação e da prática pedagógica de professores de 
língua materna.

Lívia Suassuna é Doutora em Linguística pela Universidade Estadual de Campinas UNICAMP, na qual foi orientada por João Wanderley Geraldi. Desde 1997, é professora do Centro de Educação - CE da Universidade Federal de Pernambuco - UFPE. Nessa instituição de ensino, ela atua nos cursos de graduação (Letras e Pedagogia), assim como no Programa de Pósgraduação em Educação (Mestrado e Doutorado). Seus trabalhos estão situados no âmbito da Linguística Aplicada, focando nas temáticas alusivas à metodologia do ensino de Língua Portuguesa e de Literatura nas distintas etapas da Educação Básica. Nesse âmbito, a referida autora possui alguns livros publicados. São eles: Ensino de Língua Portuguesa - uma abordagem pragmática, Ensino de Língua Portuguesa na Educação Básica, Avaliação em Língua Portuguesa - contribuições para a prática pedagógica, Ensaios de Pedagogia da Língua Portuguesa, entre outros. Além de livros, a autora possui um vasto quantitativo de textos acadêmicos publicados. Dentre estes, podemos destacar: artigos científicos, capítulos de livros e trabalhos publicados em anais de eventos. Tais trabalhos focam em distintas questões tocantes ao ensino de língua materna, como, por exemplo, o currículo de Língua Portuguesa no âmbito da Educação Básica, os eixos didáticos do ensino de língua materna (leitura, produção de texto escrito, oralidade e análise linguística), a formação de professores de língua, a avaliação da aprendizagem no ensino de língua etc.

ENTREVISTADORES: IDentre as abordagens teóricas dos postulados linguísticos, está a Linguística de Texto ou Linguística Textual. Como pode ser definida a Linguística de Texto?

Lívia Suassuna: Há uma certa controvérsia em torno da existência ou não de um ramo específico da Linguística chamado Linguística de Texto. Pessoalmente, não me detenho na polêmica e procuro ver o que há de produtivo nos princípios teóricos e métodos de análise que permitem ver o texto em sua globalidade, bem como seus mecanismos de organização. Na verdade, áreas como, por exemplo, a Análise do Discurso, a Semântica Argumentativa, a Pragmática e a Linguística Textual são fronteiriças. Eu diria que, na comparação com a Análise do Discurso, a Linguística de Texto trata mais do texto como uma unidade de sentido engendrada por uma espécie de "arquitetura", e a Análise do Discurso considera mais fortemente a questão das condições sóciohistóricas e ideológicas de produção do sentido. Em termos do ensino de língua portuguesa, no entanto, definir os limites entre esses ramos científicos é menos importante do que se valer das contribuições que todos eles trouxeram para que professores e alunos pudessem entender e praticar a língua em sua dimensão enunciativa, social e cultural.

ENTREVISTADORES: Sob a ótica da Linguística de Texto e de outros postulados linguísticos sociointeracionistas, como pode ser definida a produção de texto?

Lívia Suassuna: Como disse anteriormente e como está pressuposto na pergunta, não foi apenas a Linguística de Texto que contribuiu para redefinirmos texto, escrita e ensino-aprendizagem da 
escrita. Além das correntes já citadas, o campo dos estudos do letramento também tem tido muita importância para a construção de um novo entendimento do que é de fato um texto, de como funciona a escrita numa sociedade letrada, do que é necessário dominar para efetivamente ser um produtor de textos proficiente. Gosto muito da distinção que, nos anos 1980, o professor João Wanderley Geraldi estabeleceu entre redação e texto. A primeira seria resultante de tarefas tipicamente escolares e sua avaliação se detém na superfície estrutural e em aspectos gramaticais e ortográficos. É o que Geraldi chamou de escrever para a escola. No caso do texto, ele resultaria de processo autêntico de interação, que envolve interlocutores, um projeto de dizer (o qual implica, por sua vez, ter razões para dizer), condições históricas e sociais de enunciação e modos de dizer; a avaliação de um texto produzido nesses termos funcionaria como um trabalho dialógico, de escuta verdadeira, uma vez que o avaliador se posiciona como o outro sujeito histórico, destinatário do dizer do locutor.

\section{ENTREVISTADORES: Quais as diferenciações entre a produção de texto escrito e oral?}

Lívia Suassuna: Diferentemente do que se fazia tempos atrás, não estabelecemos mais uma oposição estrita entre fala e escrita. Elas diferem entre si em alguma medida e se assemelham bastante também em outra medida. Fala e escrita são modalidades de uma mesma língua e o que as diferencia de maneira evidente e imediata é o modo de realização, o suporte material - som ou letra. Novamente pensando no ensino de português, temos duas grandes contribuições advindas desse campo de estudos. A primeira é a ideia do "continuum" de produção linguística, muito bem explorada pelo professor Luiz Antônio Marcuschi em seu clássico livro "Da fala para a escrita atividades de retextualização". O “continuum” significa que, no uso concreto da linguagem, nós, enquanto falantes, transitamos por uma larguíssima faixa de possibilidades; nos extremos dessa faixa, teoricamente, teríamos a fala informal e a escrita formal. A outra grande contribuição é que as diferenças entre fala e escrita (repito: diferenças e não oposições), uma vez bem descritas e compreendidas, passaram a ser algo ensinável e de grande valor para aprender a escrever. Num texto de 2009, intitulado "O desenvolvimento do conhecimento linguístico-discursivo: o que se aprende quando se aprende a escrever?", a professora Maria da Graça Costa Val sustenta que há um conhecimento linguístico-discursivo específico a se desenvolver quando se aprende a escrever, e que a escrita requer um grande exercício de descentramento e abstração, de deslocamento do presente concreto imediato, em comparação com a fala. Nesse sentido, os estudos mais recentes sobre fala e escrita e suas relações são muito produtivos para a didática e a avaliação da escrita e também da oralidade.

ENTREVISTADORES: Historicamente, quais os reflexos da concepção de linguagem como representação do pensamento e da concepção de linguagem como instrumento de 
comunicação sobre o trabalho pedagógico do ensino da produção escrita? Quais os principais tratamentos alavancados por tais concepções de linguagem?

Lívia Suassuna: Do ponto de vista do ensino da escrita e do ensino de língua portuguesa em geral, as concepções de linguagem como expressão do pensamento e como instrumento de comunicação são limitadas exatamente porque nenhuma delas contempla a exterioridade constitutiva da linguagem. No primeiro caso, pensa-se que o sujeito é a fonte do sentido e, no segundo caso, a ênfase recai sobre o código, quando, na verdade, a produção da linguagem é um processo simbólico altamente complexo e dinâmico, para o qual concorrem vários elementos simultaneamente. Então, em termos do ensino da escrita, mais do que trabalhar estritamente com as regras de um código ou escrever a partir de um tema dado para expressar o conteúdo interior de alguém, trata-se de ampliar as possibilidades de interação a distância, explorando as múltiplas possibilidades que a linguagem nos oferece e permitindo aos sujeitos se engajarem no que Bakhtin chamou de "cadeia discursiva".

ENTREVISTADORES: Quais os reflexos da concepção de linguagem como forma de interação sobre o trabalho pedagógico do ensino da produção de texto escrito? Quais as principais modificações alavancadas por essa concepção de linguagem?

Lívia Suassuna: Os reflexos da concepção sociointeracionista foram muitos, entre eles: o reconhecimento da linguagem como prática histórica e social; a ampliação do entendimento de como a linguagem funciona para produzir sentido; o reconhecimento da diversidade textual; a busca por garantir que o ensino de português leve à ampliação de nossas capacidades interlocutivas; a mudança dos conteúdos e das metodologias de ensino; a construção de um novo enfoque para a avaliação da aprendizagem. Em termos da produção escrita, de 30 anos para cá, mais ou menos, procuramos, numa perspectiva sociointeracionista, assegurar que o escrever resulte de interações autênticas, nas quais os alunos tenham assegurada a palavra e, uma vez que assumam o lugar de sujeitos de seu dizer, disponham dos saberes para fazer isso.

ENTREVISTADORES: Na sua visão, o que é ser um produtor de texto competente e/ou proficiente? Quais as habilidades requeridas desse sujeito na sociedade atual?

Lívia Suassuna: O produtor de texto proficiente é aquele que deseja e sabe realizar o seu projeto de dizer. Nesse sentido, ele deve ser formado de modo a entender que, na dinâmica do discurso, somos locutores e interlocutores alternadamente. Posicionados no mundo, temos sempre algo a dizer sobre ele e, uma vez que queremos dizer algo, podemos dispor dos muitos modos de dizer. Este é o trabalho a ser feito pela escola: criar/dinamizar variadas situações interativas em que os alunos se engajem como autores e conheçam suficientemente a língua para fazê-lo. É um trabalho de muitos anos, que exige paralelamente, inclusive, uma prática intensiva de leitura, oralidade e reflexão sobre como funciona essa prática fascinante que é a linguagem. 
ENTREVISTADORES: Como o(a) professor(a) de língua pode atuar, no sentido de formar produtores de texto competentes e proficientes?

Lívia Suassuna: São muitas as condições a serem preenchidas para ensinar alguém a escrever autonomamente e o espaço desta entrevista é pequeno para detalharmos todas elas. No entanto, eu diria que duas condutas docentes são fundamentais: a primeira é que nós, professores, temos que verdadeiramente assumir o lugar de interlocutores privilegiados de nossos alunos, orientandoos, replicando seus dizeres, propondo novos conteúdos, numa atitude de real interesse por eles enquanto sujeitos sociais e de discurso; a segunda - e tenho me empenhado muito nisso ultimamente - é que não me parece possível ensinar a escrever sem que, no processo de avaliação, tenhamos o retorno ao texto, a revisão com reflexão, a reescrita para tentar dizer sempre melhor. A escola precisa praticar essa avaliação para formar bons produtores de texto.

\section{REFERÊNCIAS}

BRASIL, Secretaria de Educação Básica. Orientações Curriculares para o Ensino Médio. Secretaria de Educação Básica. - Brasília: Ministério da Educação, 2006. 239 p. (Linguagens, Códigos e suas Tecnologias; volume 1) Disponível em: <http://portal.mec.gov.br/seb/arquivos/pdf/book volume 01 internet.pdf > Acesso em: 31 ago. 2017.

BRASIL. Secretaria de Educação Fundamental. Parâmetros Curriculares Nacionais: Língua Portuguesa. Secretaria de Educação Fundamental. Brasília, 1998.

Secretaria de Educação Fundamental. Parâmetros Curriculares Nacionais: Língua Portuguesa. Secretaria de Educação Fundamental. Brasília, 1997.

CAVALCANTE, M. C. B.; MARCUSCHI, B. Formas de observação da oralidade e da escrita em gêneros diversos. In: MARCUSCHI, L.; DIONÍSIO, A. P.Fala e escrita. Belo Horizonte: Autêntica, 2007, Pp. 123-144.

KOCH, I. G. V.; ELIAS, V. M. Ler e escrever: estratégias de produção textual. São Paulo: Editora Contexto, 2009.

LEAL, T. F.; MELO, K. L. R.. Produção de textos na escola: uma introdução ao tema. In: LEAL, T. F.. BRANDÃO, A. C. P.. Produção de textos na escola: reflexões e práticas no Ensino Fundamental. Belo Horizonte: Autentica, 2007. Pp. 11-27.

LUNA, T. S. A constituição da autoria em crônicas. In: Anais da XXIV JORNADA DO GELNE. Natal: EDUFRN, 2012. p. 1-13. Disponível em: <https://www.yumpu.com/pt/document/view/16081023/a-constituicao-da-autoria-em-cronicastatiana-gelne>. Acesso em: 13 ago. 2017.

MARCUSCHI, B. Escrevendo na escola para a vida. In: RANGEL, E. O.; ROJO, R. (Orgs.). Língua Portuguesa: ensino fundamental. Brasília: Ministério da Educação, Secretaria de Educação Básica, 2010, pp. 65-84. Disponível em: http://portal.mec.gov.br/index.php?option=com_docman\&view=download\&alias=7840-2011lingua-portuguesa-capa-pdf\&category slug=abril-2011-pdf\&Itemid=30192; Acesso em: 26 ago. 2017. 
SANTOS, C. F. Formação em Serviço do Professor e as Mudanças no Ensino de Língua Portuguesa. Educação Temática Digital - ETD, Campinas, vol. 3, n. 2, pp. 27-37, jun. 2002. Disponível em: https://periodicos.sbu.unicamp.br/ojs/index.php/etd/article/view/605. Acesso em: 07 set. 2017. 